\title{
Phytochemical Analysis and Antimalarial Activity Aqueous Extract of Lecaniodiscus cupanioides Root
}

\author{
Mikhail Olugbemiro Nafiu, Taoheed Adedeji Abdulsalam, and Musbau Adewumi Akanji \\ Department of Biochemistry, University of Ilorin, P. M. B. 1515 Ilorin, Nigeria \\ Correspondence should be addressed to Mikhail Olugbemiro Nafiu; olumikail@gmail.com
}

Received 16 April 2013; Revised 26 June 2013; Accepted 14 July 2013

Academic Editor: Marcel Tanner

Copyright (C) 2013 Mikhail Olugbemiro Nafiu et al. This is an open access article distributed under the Creative Commons Attribution License, which permits unrestricted use, distribution, and reproduction in any medium, provided the original work is properly cited.

\begin{abstract}
Root aqueous extract of Lecaniodiscus cupanioides was evaluated for antimalarial activity and analyzed for its phytochemical constituents. Twenty-four (24) albino mice were infected by intraperitoneal injection of standard inoculum of chloroquine sensitive Plasmodium berghei (NK 65). The animals were randomly divided into 6 groups of 3 mice each. Group 1 served as the control while groups II-IV were orally administered 50,150, and $250 \mathrm{mg} / \mathrm{kg}$ body weights of extract. Groups 5 and 6 received $1.75 \mathrm{and} 5 \mathrm{mg} / \mathrm{kg}$ of artesunate and chloroquine, respectively. The results of the phytochemical analysis showed the presence of alkaloids (2.37\%), saponin (0.336), tannin ( 0.012 per cent), phenol (0.008 per cent), and anthraquinone ( 0.002 per cent). There was 100 per cent parasite inhibition in the chloroquine group and 70 per cent in the $50 \mathrm{mg} / \mathrm{kg}$ body weight on day 12 , respectively. The mean survival time (MST), for the control group was 14 days, artesunate 16 days, and chloroquine 30 days, while the groups that received 50 and $250 \mathrm{mg} / \mathrm{kg}$ body weight recorded similar MST of 17 days and the $150 \mathrm{mg} / \mathrm{kg}$ body weight group recorded 19 days. The results obtained indicated that the aqueous extract of Lecaniodiscus cupanioides may provide an alternative antimalarial.
\end{abstract}

\section{Introduction}

Malaria is an enormous health, social, and economic burden for over $40 \%$ of the world's population. It remains one of the most important infectious diseases of mankind, killing 1-3 million people and causing morbidity in more than 500 million people annually [1]. Almost 90 per cent of the deaths from malaria occur in sub-Saharan Africa, where the vulnerable groups are children under 5 years and the pregnant women [2].

The control of malaria is hampered by the rapid selection of parasites resistant to antimalarials. Indeed, there is no single antimalarial in clinical use to which the parasite has not yet developed resistance [3, 4]. Antimalaria drug resistance has become one of the greatest challenges against malaria control. There is widespread multidrug resistance to common antimalarial drugs $[1,5]$.

Rodent plasmodia such as Plasmodium berghei are commonly used as malaria models in mice and have tremendous impact on the investigations of antimalarial activities of plant extracts. The need to search and develop more effective antimalarial drugs that are inexpensive and readily available to people in the developing countries like Nigeria has necessitated this study. Medicinal plants have been the focus of many anti-infective drugs and alternative sources of antimalarial agents in various parts of the world since long ago [6]. One of such plants claimed to possess antimalarial activities is root of Lecaniodiscus cupanioides.

Lecaniodiscus cupanioides is a tropical plant widely distributed in Africa and Asia. It belongs to the Sapindaceae family and it is identified by various names in Nigeria, such as Ukpo (Igbo), Utantan (Edo), Kafi-nama-zaki (Hausa), and Akika (Yoruba). The plant is ethnomedically reputed to be useful in the treatment of wounds and sores, abdominal swelling caused by liver abscess, fevers, measles, hepatomegaly and burns, among others [7]. The present study was carried out to assess the antimalarial activities of the aqueous extract of root of Lecaniodiscus cupanioides in mice. 


\section{Materials and Methods}

2.1. Plant Materials. The root of Lecaniodiscus cupanioides (Sapindaceae) was obtained from "Oja-Oba," Ilorin, Kwara state, and was identified in the Department of Plant Biology, University of Ilorin, Ilorin, Kwara state, Nigeria

2.2. Aqueous Extraction. The root of the plant was air-dried to constant weight and ground into powdered form with an electric milling machine. Aqueous extract was prepared by soaking $200 \mathrm{~g}$ of the powered root in 1.2 liters of distilled water for 24 hours in amber colored bottles. The contents of the bottles were filtered with Whatman no. 1 filter paper and the filtrate collected was evaporated to dryness with steam on water bath $\left(40^{\circ} \mathrm{C}\right)$. The dried extract was weighed and reconstituted into desired doses.

2.3. Phytochemical Analysis. A portion of the root powder was subjected to phytochemical analysis, using standard chemical test as described by $[8,9]$.

2.4. Experimental Animals. Albino mice with average weight of $21.1 \mathrm{~g}$ were obtained from the small Animal Holding Unit, Department of Biochemistry, University of Ilorin, Ilorin, Nigeria. The animals were housed in well ventilated plastic cages under standard conditions, and the study was conducted in accordance with the recommendations from the declaration of Helsinki on guiding principles in the care and use of animals.

2.5. Drugs and Reagents. Artesunate used in this study was obtained from Mekophar Chemical Pharmaceutical Joint Stock Company, Vietnam, while chloroquine was from May and Baker Pharmaceutical Company Limited, Nigeria. Other reagents were of analytical grade and were prepared in all glass bottles.

2.6. Malaria Parasite. Plasmodium berghei (chloroquine sensitive NK65 strain) was obtained from the Institute for Advanced Medical Research and Training (IMRAT), College of Medicine, University of Ibadan, Ibadan Nigeria.

2.7. Inoculation of Experimental Mice. Albino mice were infected by intraperitoneal injection of standard inoculum $\left(0.2 \mathrm{~mL}\right.$ of $1 \times 10^{7}$ infected erythrocytes $)$ from a single donor mouse previously infected with Plasmodium berghei (29 per cent parasitemia).

2.8. Animal Groupings. The animals were randomly divided into 6 groups of 3 mice each, after confirmation of parasitaemia 72 hours after infection. Group 1 (control) was left untreated but administered appropriate volume of distilled water. Groups 2, 3, and 4 were administered aqueous extract of Lecaniodiscus cupanioides through oropharyngeal canulla at the doses of 50,150 , and $250 \mathrm{mg} / \mathrm{kg}$ body weight, respectively. Group 5 received artesunate at a dose of $1.75 \mathrm{mg} / \mathrm{kg}$ body weight daily for 3 days while Group 6 animals were treated with $5 \mathrm{mg} / \mathrm{kg}$ body weight of chloroquine for the same period.

2.9. Estimation of Percentage Parasitaemia. Percentage parasitemia was estimated at the end of the observational period of 28 days using the formula

$$
\frac{\text { parasitized RBC }}{\text { parasitized RBC + nonparasitized RBC }} \times 100 \text {. }
$$

2.10. Estimation of Percentage Chemosuppression. The percentage chemo-suppression of parasite multiplication per days was calculated by using the formula

$$
\text { \% chemo-suppression } A=\frac{B-C}{C} \times 100 \text {, }
$$

where $B$ = parasitaemia in study group, $C=$ parasitaemia in control.

2.11. Estimation of Mean Survival Time (MST). The number of days each animal survived was recorded for the animals in each group and mean survival time calculated using the formula

$$
\text { MST }=\frac{\text { sum of days of survival of animals/group }}{\text { total number of animals in the group }} .
$$

2.12. Statistical Analysis. Data were presented as mean of three determinations \pm SEM. Statistical analysis was carried out using one-way analysis of variance (ANOVA). Differences were considered statistically significant at $P<0.05$.

\section{Results}

Qualitative and quantitative screening of the components of the plant root revealed the phytochemicals shown in Table 1. The phytochemicals that were present included Alkaloids, saponin, tannins, phenol and anthraquinone.

3.1. Percentage Parasitaemia. Estimation of percentage parasitemia at the end of 12 days showed the results in Figure 1. The $50 \mathrm{mg} / \mathrm{kg}$ body weight of the extract prevented further increase in the baseline parasitaemia until after day 8 before a noticeable rise in parasitaemia was observed. The 150 and $250 \mathrm{mg} / \mathrm{kg}$ body weights of the extract also initially reduced the parasitaemia baseline parasitaemia at day 5 but could not maintain the reduction compared to the $50 \mathrm{mg} / \mathrm{kg}$ body weight. A reduction in baseline parasitaemia was observed in the artesunate treated group before resurgence was in the level on day 6. Chloroquine reduced the parasitaemia level throughout the experimental days.

3.2. Mean Survival Time (MST). Table 2 showed the mean survival time for the animals in each group. The least MST of 14 days was recorded for the control group that was left untreated. The mice in the artesunate group recorded MST of 16 days. The MST of 17 days was recorded for the groups that 
TABle 1: Parasitaemia changes following treatment with different doses of aqueous extract of Lecaniodiscus cupanioides and standard drugs.

\begin{tabular}{|c|c|c|c|c|c|c|c|}
\hline \multirow{2}{*}{ Treatments } & \multicolumn{7}{|c|}{ Days } \\
\hline & 4 & 5 & 6 & 7 & 8 & 9 & 12 \\
\hline Control & $1.80 \pm 0.12^{\mathrm{a}}$ & $0.83 \pm 0.08^{\mathrm{a}}$ & $1.90 \pm 0.40^{\mathrm{a}}$ & $1.97 \pm 0.14^{\mathrm{a}}$ & $5.53 \pm 1.98^{\mathrm{b}}$ & $6.60 \pm 1.41^{\mathrm{cb}}$ & $9.47 \pm 1.18^{\mathrm{c}}$ \\
\hline Chloroquine & $1.80 \pm 0.12^{\mathrm{a}}$ & $0.40 \pm 0.40^{\mathrm{b}}$ & $0.27 \pm 0.27^{\mathrm{b}}$ & $0.23 \pm 0.23^{\mathrm{b}}$ & $0.20 \pm 0.00^{\mathrm{b}}$ & $0.80 \pm 0.29^{\mathrm{b}}$ & $0.40 \pm 0.17^{\mathrm{b}}$ \\
\hline Artesunate & $1.80 \pm 0.12^{\mathrm{a}}$ & $1.10 \pm 0.59^{\mathrm{a}}$ & $1.40 \pm 0.70^{\mathrm{a}}$ & $2.07 \pm 1.03^{\mathrm{a}}$ & $4.43 \pm 2.41^{\mathrm{ab}}$ & $4.33 \pm 0.53^{\mathrm{ab}}$ & $7.50 \pm 2.82^{\mathrm{a}}$ \\
\hline $50 \mathrm{mg} / \mathrm{kg}$ b.wt extract & $1.80 \pm 0.12^{\mathrm{a}}$ & $1.00 \pm 0.58^{\mathrm{a}}$ & $0.43 \pm 0.43^{\mathrm{a}}$ & $0.73 \pm 0.38^{\mathrm{a}}$ & $0.23 \pm 0.12^{\mathrm{a}}$ & $2.10 \pm 0.45^{\mathrm{a}}$ & $2.10 \pm 1.3^{\mathrm{a}}$ \\
\hline $150 \mathrm{mg} / \mathrm{kg}$ b.wt extract & $1.80 \pm 0.12^{\mathrm{a}}$ & $0.53 \pm 0.53^{\mathrm{a}}$ & $1.00 \pm 1.00^{\mathrm{a}}$ & $1.33 \pm 1.33^{\mathrm{a}}$ & $3.50 \pm 1.75^{\mathrm{a}}$ & $3.40 \pm 1.70^{\mathrm{a}}$ & $3.50 \pm 0.35^{\mathrm{a}}$ \\
\hline $250 \mathrm{mg} / \mathrm{kg}$ b.wt extract & $1.80 \pm 0.12^{\mathrm{a}}$ & $2.07 \pm 0.54^{\mathrm{a}}$ & $1.90 \pm 0.00^{\mathrm{a}}$ & $1.67 \pm 0.83^{\mathrm{a}}$ & $2.40 \pm 1.44^{\mathrm{a}}$ & $5.30 \pm 0.00^{\mathrm{b}}$ & $12.47 \pm 1.07^{\mathrm{c}}$ \\
\hline
\end{tabular}

Data are mean of 3 replicates \pm SEM. Values carrying different superscripts from the control along the rows are significantly different $(P<0.05)$.

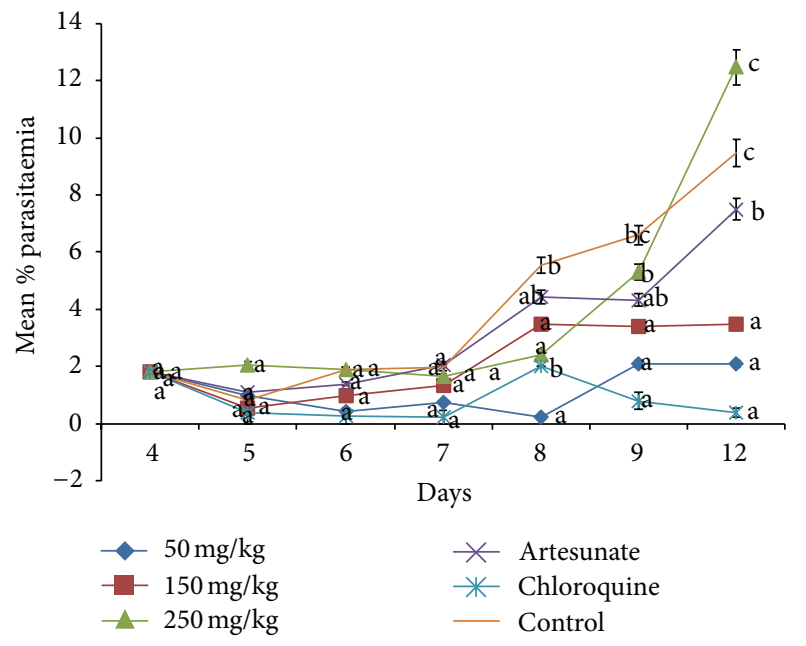

FIGURE 1: Parasitaemia changes following treatment with different doses of aqueous extract of Lecaniodiscus cupanioides and standard drugs. Values carrying different superscript from the control are significantly different $(P<0.05)$.

received 50 and $250 \mathrm{mg} / \mathrm{kg}$ while 19 days were recorded for the group that received $150 \mathrm{mg} / \mathrm{kg}$ body weight of the extract. MST of 30 days was recorded for chloroquine.

\section{Discussion}

The phytochemical analysis of the aqueous root extract of Lecaniodiscus cupanioides revealed the presence of alkaloids, saponin tannin, phenol, and anthraquinone. Alkaloids have been implicated in antimalarial activity of many plants [10]. The extract of Nigella sativa (black seed) contained different classes of alkaloids that were believed to block protein synthesis in Plasmodium falciparum [11]. Triterpenoid and steroid saponins have been found to be detrimental to several infectious protozoans such as Plasmodium falciparum [12].

Although primate models provide a better prediction of efficacy in humans than the rodent models, the latter have also been validated through the identification of several conventional antimalarials, such as chloroquine, halofantrine, mefloquine, and more recently artemisinin derivatives [13]. $P$. berghei are used in the prediction of treatment outcomes. Hence it was an appropriate parasite for the study. As this
TABLE 2: Phytochemical constituents of the aqueous root extract of Lecaniodiscus cupanioides.

\begin{tabular}{lc}
\hline Phytochemicals & Percentage \\
\hline Alkaloids & 2.37 \\
Saponin & 0.336 \\
Tannin & 0.012 \\
Phenol & 0.008 \\
Anthraquinone & 0.002 \\
Steroids & nd \\
Phlobatannin & nd \\
Terpenes & nd \\
Cardiac glycosides & nd \\
Flavonoids & nd \\
\hline
\end{tabular}

nd: not detected.

parasite is sensitive to chloroquine, this drug was employed as a standard drug in this study.

Rane test is a standard test commonly used for antimalarial screening. It relies on the ability of standard inoculum of $P$. berghei to kill the recipient mouse thereafter. The extension of survival by the test compound beyond 12 days is regarded as active [14].

When a standard antimalarial drug is used in mice infected with $P$. berghei, it suppresses parasitaemia to nondetectable level [15], which is in agreement with the effect of chloroquine in this study. Results from this study showed that the aqueous root extract of L. cupanioides possesses antimalarial activity that was comparable to that of chloroquine. The observed antimalarial activity was not dose dependent but at a dose of $50 \mathrm{mg} / \mathrm{kg}$ body weight a reduction in parasitaemia was recorded with 70 per cent chemo-suppression on day 12 (Table 4). It was also reported that potent antimalarial activities exhibited by Eurycoma longifolia with $80 \%$ parasitaemia inhibition at $10 \mathrm{mg} / \mathrm{kg}$ and Ardisia crispa [16]. The high parasitaemia obtained at 150 and $250 \mathrm{mg} / \mathrm{kg}$ of the extract compared to $50 \mathrm{mg} / \mathrm{kg}$ after the fifth day (Figure 1) may mean that at higher doses the extract exacerbated the infection. This may be due to immunosuppressive activity of the extract. It had been reported that oral administration of phytochemicals like saponin, tannins, and phenols possessed ability to suppress cellular immunity [17]. 
TABLE 3: Mean survival time of animals for the experiment.

\begin{tabular}{lc}
\hline Group & Mean survival time (days) \\
\hline Control & 14 \\
$50 \mathrm{mg} / \mathrm{kg}$ & 17 \\
$150 \mathrm{mg} / \mathrm{kg}$ & 19 \\
$250 \mathrm{mg} / \mathrm{kg}$ & 17 \\
Artesunate & 16 \\
Chloroquine & 28 \\
\hline
\end{tabular}

TABle 4: Percentage chemosuppression of parasitaemia by the aqueous root extract of L. cupanioides and standard drugs.

\begin{tabular}{lcccccc}
\hline & \multicolumn{5}{c}{$\begin{array}{c}\text { Days } \\
\text { \% suppression }\end{array}$} \\
\hline Group & 5 & 6 & 7 & 8 & 9 & 12 \\
$50 \mathrm{mg} / \mathrm{kg}$ & 60 & 60 & 60 & 90 & 70 & 70 \\
$150 \mathrm{mg} / \mathrm{kg}$ & 60 & 30 & 30 & 50 & 60 & 10 \\
$250 \mathrm{mg} / \mathrm{kg}$ & 50 & 40 & 30 & 20 & 20 & 20 \\
Artesunate & 50 & 20 & 30 & 20 & 30 & 10 \\
Chloroquine & 70 & 90 & 90 & 60 & 90 & 100 \\
\hline
\end{tabular}

The determination of percentage inhibition of parasitaemia is the most reliable parameter in antimalarial screening. A mean group parasitaemia level of less than or equal to 90 per cent of that of treated control animals usually indicates that the test compound is active in standard screening studies [14]. Therefore, it is clear from the result (Table 3) that the $P$. berghei-infected mice treated with the aqueous root extract of L. cupanioides reduced in percentage parasitaemia compared to those of the untreated control animals. The possible active compounds responsible for the antimalarial activity of $L$. cupanioides may be alkaloid and saponin. The results from this study, therefore, lent scientific credence to the folkloric use of the root extract of L. cupanioides for the treatment of malaria in Africa.

\section{Conclusion}

The present study revealed that oral administration of aqueous root extract of $L$. cupanioides exhibited antimalarial activity in $P$. berghei-infected mice. This suggests the beneficial effects of the herb. It is, however, very important to note that the extract at $50 \mathrm{mg} / \mathrm{kg}$ body weight showed the best action. The effect of the extract compared favourably with chloroquine and artesunate. These findings have lent scientific support to the folkloric use of aqueous root extract of $L$. cupanioides.

\section{References}

[1] WHO, The Word Malaria Report From WHO and UNICEF World Health Organization, Geneva, Switzerland, 2005.

[2] WHO, Making a difference: Rolling Back Malaria: The World Health Report, 1999.

[3] N. J. White, "Antimalarial drug resistance," Journal of Clinical Investigation, vol. 113, no. 8, pp. 1084-1092, 2004.
[4] A. Nzila, "Inhibitors of de novo folate enzymes in Plasmodium falciparum," Drug Discovery Today, vol. 11, no. 19-20, pp. 939944, 2006.

[5] F. W. Muregi, S. C. Chhabra, E. N. M. Njagi et al., "In vitro antiplasmodial activity of some plants used in Kisii, Kenya against malaria and their chloroquine potentiation effects," Journal of Ethnopharmacology, vol. 84, no. 2-3, pp. 235-239, 2003.

[6] B. G. Schuster, "Demonstrating the validity of natural products as anti-infective drugs," Journal of Alternative and Complementary Medicine, vol. 7, no. 1, pp. S73-S82, 2001.

[7] O. K. Yemitan and O. O. Adeyemi, "CNS depressant activity of Lecaniodiscus cupanioides," Fitoterapia, vol. 76, no. 5, pp. 412418, 2005.

[8] G. E. . Trease and W. C. Evans, A Text-Book of Pharmacognosy, Bailliere Tindall, London, UK, 1989.

[9] A. Sofowora, Medicinal Plants and Traditional Medicines in Africa, John, Willey \& Sons, Chichester, UK, 1993.

[10] S. B. Christenzen and A. Kharazmi, "Antimalari natural products isolation characterization and biological properties," Bioactive Compounds from Natural Sources Isolation Characterization and Biological Properties, pp 379-432, 2001.

[11] H. A. A. . Abdulelah and B. A. H. Zainal-Abidin, "In vivo Antimalaria tests of Nigella sativa (Black Seed) different extracts," American Journal of Pharmacology and Toxicology, vol. 2, no. 2, pp. 46-50, 2007.

[12] F. Delmas, C. Di Giorgio, R. Elias et al., "Antileishmanial activity of three saponins isolated from ivy, $\alpha$ - hederin, $\beta$-hederin and hederacolchiside $\mathrm{Al}$, as compared to their action on mammalian cells cultured in vitro," Planta Medica, vol. 66, no. 4, pp. 343-347, 2000.

[13] A. F. David, J. R. Philip, L. C. Simon, B. Reto, and N. Solomon, "Antimalarial drug discovery: efficacy models for compound screening," Nature Reviews Drug Discovery, vol. 3, no. 6, pp. 509-520, 2004.

[14] I. T. Peter and V. K. Anatoli, The Current Global Malaria Situation. Malaria Parasite Biology, Pathogenesis, and Protection, ASM Press, Washington, DC, USA, 1998.

[15] K. Kamei, H. Matsuoka, S.-I. Furuhata et al., "Anti-malarial activity of leaf-extract of Hydrangea macrophylla, a common Japanese plant," Acta Medica Okayama, vol. 54, no. 5, pp. 227232, 2000.

[16] R. Basir, K. Chan, M. F. Yam et al., "Antimalarial activity of selected Malaysian medicinal plants," Phytopharmacol, vol. 3, no. 1, pp. 82-92, 2012.

[17] M. Sankari, V. Chitra, R. Jubilee, P. Silambu Janaki, and D. Raju, "Immunosuppressive activity of aqueous extract of Lagenaria sicerarian (standley) in mice," Scholars Research Library, vol. 2, pp. 291-296, 2010. 


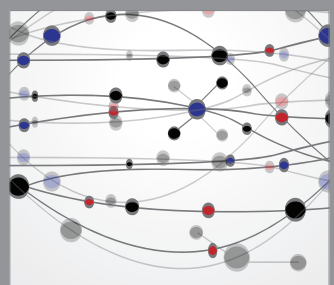

The Scientific World Journal
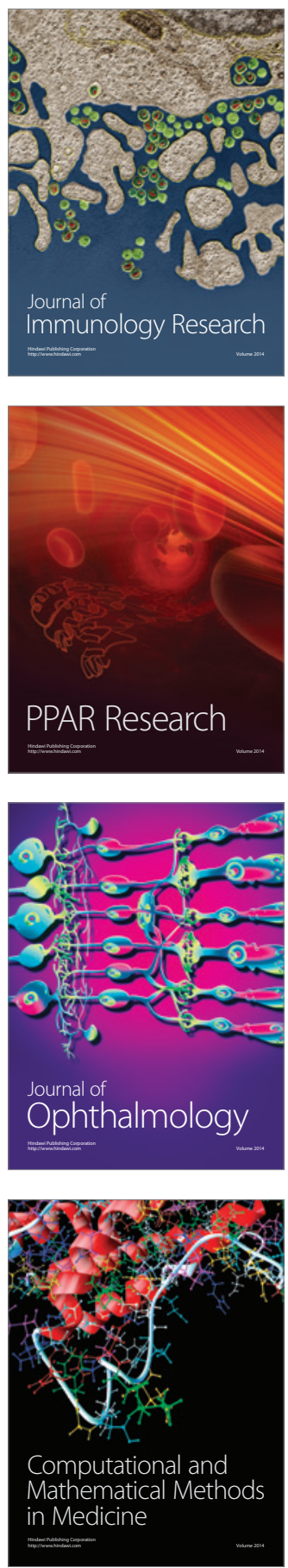

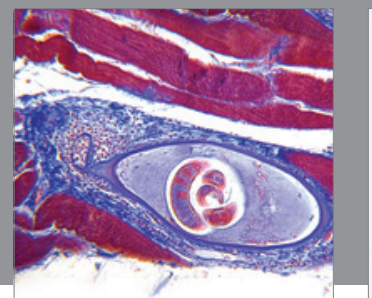

Gastroenterology

Research and Practice
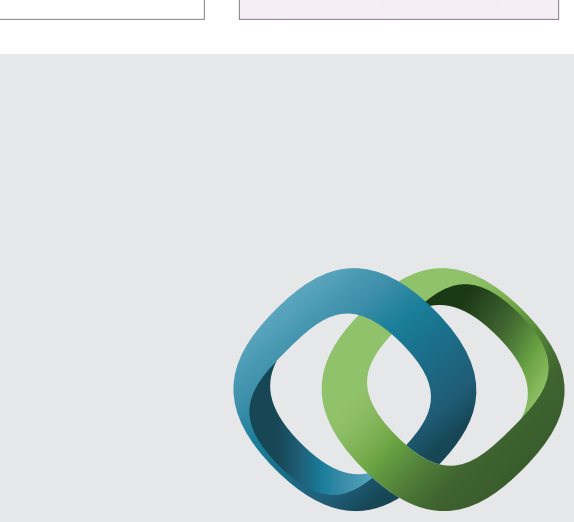

\section{Hindawi}

Submit your manuscripts at

http://www.hindawi.com
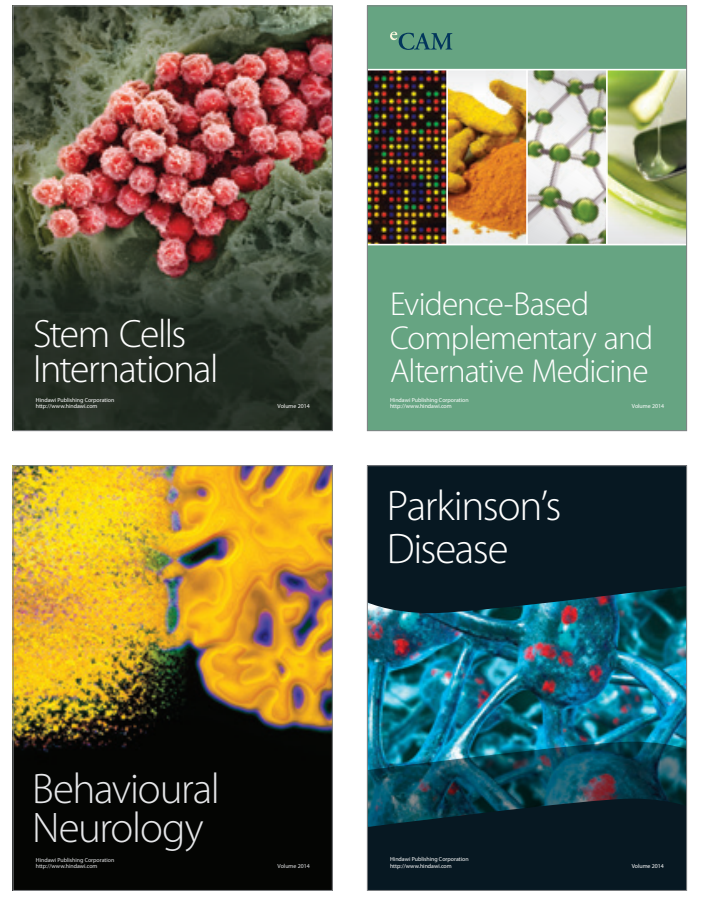
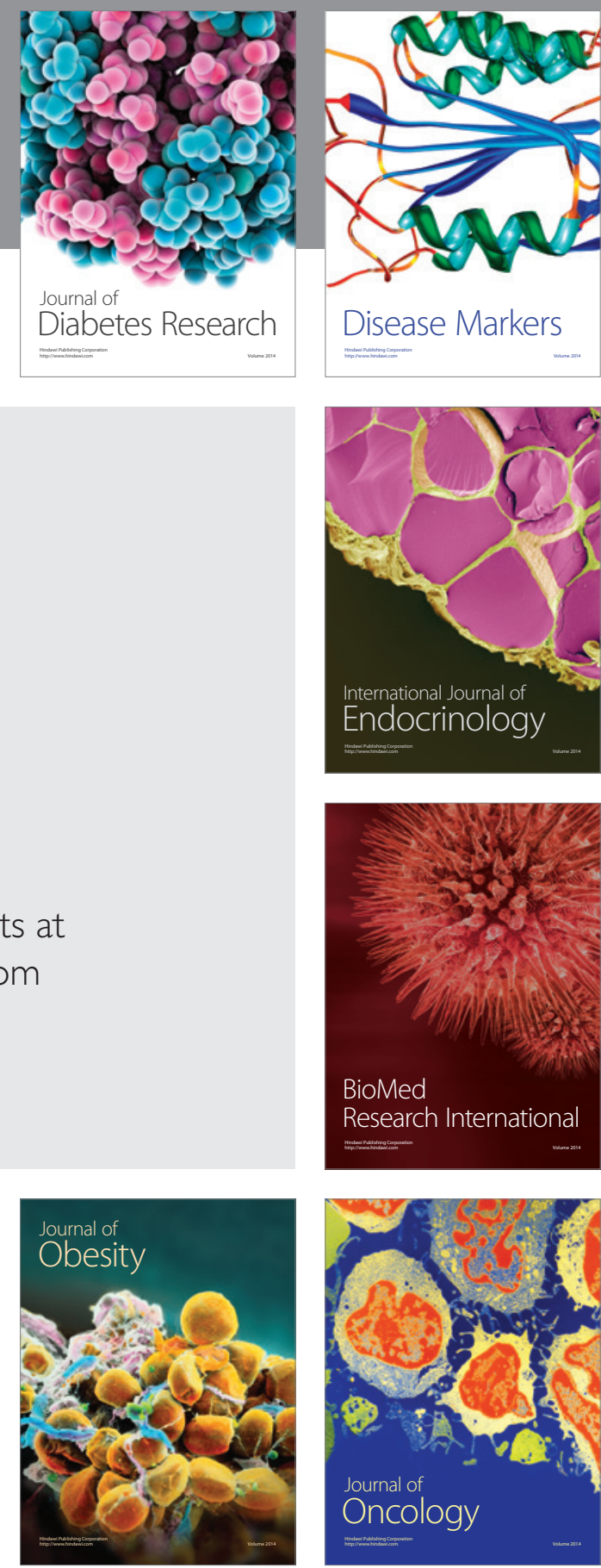

Disease Markers
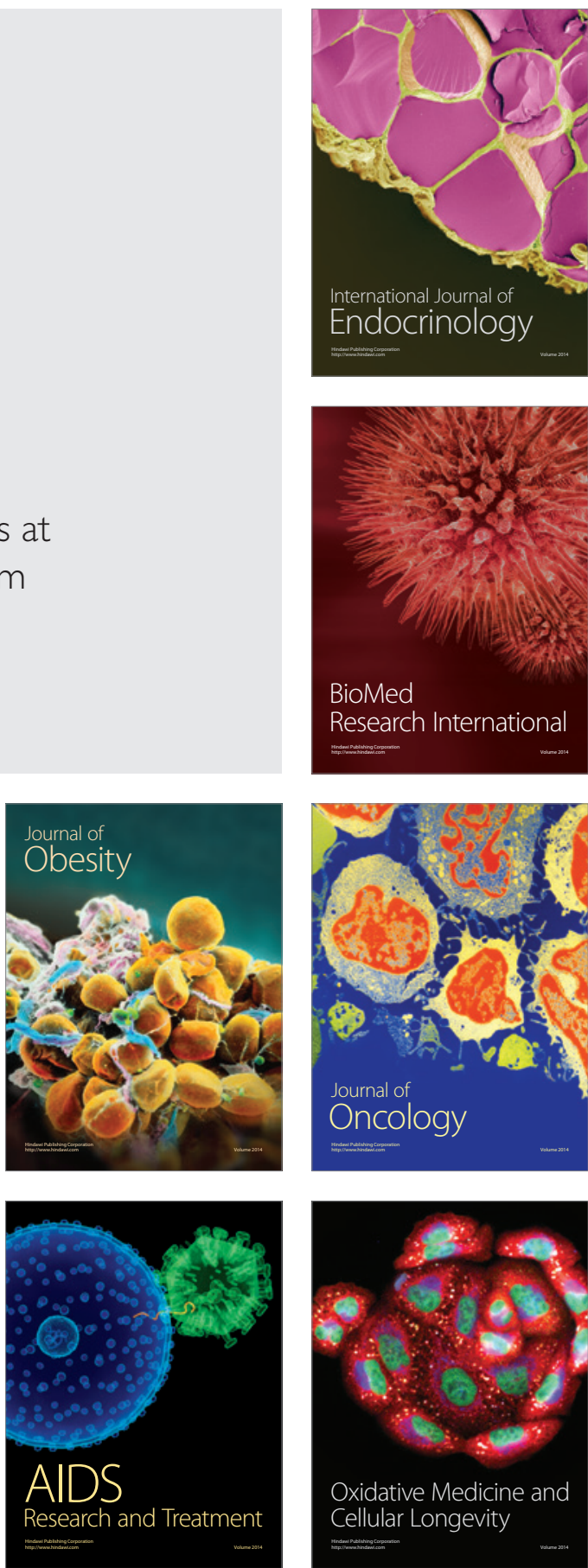